\title{
WORKSHOP HYPNOMOTIVATION PADA SMA IT AI ICHWAN CIKARANG
}

\author{
${ }^{1}$ Sutan Faisal, ${ }^{2}$ Syamsul Tri Andika \\ sutanfaisal@ubpkarawang.ac.id \\ syamsul.tri.andika@mhs.ubpkarawang.ac.id
}

Abstrak : Mengemban tugas utama seorang dosen terdiri dari tiga tridharma, yaitu pendidikan, penelitian dan pengabdian pada masyarakat. Universitas Buana Perjuangan, lewat lembaga penelitian dan pengabdian masyarakat (LPPM), berusaha memenuhi Tri Dharma tersebut dengan melakukan kegiatan pengabdian pada masyarakat, seperti workshop hypnomotivation pada siswa yang bertujuan untuk memaksimalkan kekuatan pikiran dan penguasaan emosi siswa pada akhirnya memotivasi siswa dan terasahnya kecerdasan yang berefek penongkatan prestasi belajar siswa. Tujuan dari pengabdian masyarakat ini adalah: Ingin mengetahui adakah pengaruh motivasi belajar terhadap prestasi belajar. Sasarannya adalah para siswa di SMK IT Al Ichwan Cikarang. Metode pelaksanaan kegiatan yang dilakukan pada workshop hypnomotivation ini dilakukan dengan beberapa teknik penyampaian materi yaitu ceramah, praktek, diskusi dan games. Hasil yang didapat dari pelaksanaan kegiatan pengabdian masyarakat ini diantaranya adalah siswa/siswi memahami mengenai isi materi hypnomotivation dan bisa mempraktekan untuk meningkatkan prestasinya selain itu para peserta merasa mendapatkan wawasan yang lebih luas tentang cara belajar yang efektif,

Kata Kunci : Hypnomotivation, Prestasi 
UU No. 20 Tahun 2003 Tentang SISDIKNAS menyatakan bahwa Pendidikan adalah usaha sadar dan terencana untuk mewujudkan suasana belajar dan proses pembelajaran agar peserta didik secara aktif mengembangkan potensi dirinya untuk memiliki kekuatan spiritual keagamaan, pengendalian diri, kepribadian, kecerdasan, akhlak mulia, serta keterampilan yang diperlukan dirinya, masyarakat, bangsa dan negara.

Melalui pendidikan, siswa dipersiapkan menjadi masyarakat yang cerdas dan berguna bagi Nusa dan Bangsa. Mengingat pentingnya pendidikan maka telah banyak usaha yang dilakukan pemerintah untuk meningkatkan mutu Pendidikan di Indonesia. Pendidikan merupakan investasi yang sangat penting bagi setiap bangsa dalam pembangunan kearah kemajuan.

Prestasi belajar siswa merupakan output dari proses belajar, dengan demikian faktorfaktor yang mempengaruhi proses belajar juga langsung mempengaruhi prestasi belajar. Untuk memperoleh prestasi belajar yang maksimal dengan hasil yang baik, maka harus benar-benar memperhatikan berbagai faktor yang mempengaruhinya.(Stefany Atok)

Prestasi juga dipengaruhi oleh motivasi. Menurut Wlodkowsky (dalam Sugihartono dkk, 2007) Motivasi adalah suatu kondisi yang menyebabkan atau menimbulkan perilaku tertentu dan yang memberi arah dan ketahanan pada tingkah laku tersebut. Motivasi belajar yang tinggi tercermin dari ketekunan yang tidak mudah patah untuk mencapai sukses meskipun dihadang oleh berbagai kesulitan. Adapun ciri-ciri siswa yang termotivasi belajar untuk berprestasi antara lain tekun, ulet menghadapi kesulitan, menunjukan minat terhadap bermacam-macam masalah, lebih senang bekerja sendiri, cepat bosan dengan tugas, dapat mempertahankan pendapat, senang mencari dan memecahkan masalah.

Menurut Slameto (1995: 2) bahwa belajar adalah suatu proses usaha yang dilakukan seseorang untuk memperoleh suatu perubahan tingkah laku yang baru secara keseluruhan, sebagai hasil pengalamannya sendiri dalam interaksi dengan lingkungannya. Secara sederhana dari pengertian belajar sebagaimana yang dikemukakan oleh pendapat di atas, dapat diambil suatu pemahaman tentang hakekat dari aktivitas belajar adalah suatu perubahan yang terjadi dalam diri individu.

Hipnosis adalah suatu kondisi mental (menurut state theory) atau diberlakukannya peran imajinatif (menurut non-state theory). Orang yang melakukan proses hipnosis (memberikan sugesti) terhadap subjek disebut hipnotis (bahasa inggris:hypnotist). Hipnosis biasanya disebabkan oleh prosedur yang dikenal sebagai induksi hipnosis, yang umumnya 
terdiri dari rangkaian panjang instruksi awal dan sugesti. Sugesti hipnosis dapat disampaikan oleh seorang hipnotis di hadapan subjek, atau mungkin dilakukan sendiri oleh subjek (Self-

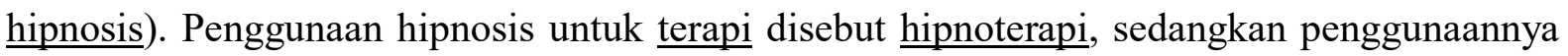
sebagai bentuk hiburan bagi penonton dikenal sebagai Stage hipnosis.(id.wikepedia.org)

Hypnomotivation berasal dari kata hypnosis dan motivation. Hypnpmotivation adalah salah satu metode untuk memberikan motivasi dengan teknik hypnosis yang bertujuan untuk melatih focus dan mlatih imaginasi untuk proses pembelajaran untuk meningkatkan prestasi akademik.

\section{METODE}

\section{A. Khalayak Sasaran Kegiatan}

Sasaran kegiatan Pengabdian Kepada Masyarakat ini adalah para siswa SMK IT AL ICHWAN Cikarang. Para siswa perlu diarahkan dan dimotivasi supaya bisa meningkatkan prestasi belajarnya. Dengan diadakannya workshop ini juga membantu para guru akan dengan mudah memberikan pelajarannya karena para siswa dapat dengan focus menerima pelajaran di sekolah

\section{B. Metode Kegiatan}

Adapun metode pelaksanaan kegiatan yang dilakukan pada workshop hypnomotivation ini dilakukan dengan beberapa teknik penyampaian materi yaitu ceramah, praktek, diskusi dan games.

\section{Langkah-langkah Kegiatan}

Secara umum langkah-langkah kegiatan Pengabdian Kepada Masyarakat ini bisa dibagi dalam tiga tahap yakni persiapan, pelaksanaan, dan evaluasi.

Pada tahap persiapan yang dilakukan adalah menganalisa masalah dan kebutuhan. Pelaksana Pengabdian Kepada Masyarakat mencari data dan informasi dari para siswa dan lingkungan sekolah. Pada tahap ini mengidentifikasi masalah dan mencari upaya untuk membantu mengatasi permasalahan yang mendesak untuk memotivasi siswa supaya berprestasi.

Tahap kedua yaitu pelaksanaan, yakni terbagi menjadi 3 sesi yaitu penyampaian materi hypnomotivation, praktek, dan selanjutnya dilakukan diskusi interaktif dengan siswa tentang permasalahan yang langsung dihadapi siswa terkait dengan proses belajar di sekolah. Selanjutnya sebagai tahap terakhir adalah evaluasi. Evaluasi ini dilakukan dengan meminta 
tanggapan dari siswa maupun pihak mitra atau sekolah atas pelaksanaan kegiatan yang telah dilakukan. Berdasarkan tanggapan yang diberikan baik dari siswa maupun sekolah menyatakan bahwa pelaksanaan pengabdian kepada masyarakat dalam bentuk hypnomotivation sangat tepat guna mempersiapkan siswa untuk meningkatkan prestasi belajarnya.

\section{HASIL DAN PEMBAHASAN}

\section{A. Hasil Pelaksanaan Kegiatan}

Hasil yang didapat dari pelaksanaan kegiatan pengabdian masyarakat ini diantaranya adalah :

1. Siswa/siswi diberikan motivasi dengan menggunakan metode hypnomotivation.

2. Dari hasil workshop, siswa/siswi memahami mengenai isi materi hypnomotivation dan bisa mempraktekannya.

\section{B. Pembahasan}

Kegiatan pengabdian masyarakat ini dilaksanakan dalam beberapa sesi sebagai berikut :

1. Penyampaian Materi Hypnomotivation

Materi Hypnomotivation yang diberikan diantaranya : memaksimalkan pikiran sadar dan bawah sadar, analogi proses belajar, cara melawan mental blok, power of word, power of focus, power of imagination dan affirmation learning.

2. Praktek

Mempraktekan cara melawan mental blok, power of word, power of focus, power of imagination dan affirmation learning

3. Diskusi Interaktif

Diskusi dengan siswa tentang permasalahan yang langsung dihadapi siswa terkait dengan proses belajar di sekolah dan mencari jalan keluar untuk penyelesaiannya.

Kegiatan pengabdian kepada masyarakat ini memberikan hasil yang sangat positif yaitu memberikan bekal pengembangan diri khususnya dalam hal peningkatan motivasi berprestasi pesertanya, baik sukses secara studi maupun pasca studi.

\section{Faktor Pendukung dan Penghambat Kegiatan}

Faktor pendukung dalam kegiatan pengabdian masyarakat ini salah satunya dukungan yang diberikan pihak sekolah baik dari kepala sekolah, guru dan siswa siswinya yang terlibat dalam pelaksanaan kegiatan pengabdian masyarakat ini. Sedangkan penghambat kegiatan 
pengabdian masyarakat ini adalah kontunitasnya siswa/siswi dalam mempraktekan ilmu yang telah diberikan dalam workshop hypnomotivation ini.

\section{SIMPULAN}

Dari kegiatan Pengabdian Kepada Masyarakat dengan topik Hypnomotivation untuk Siswa tingkat XII SMA IT Al Ichwan Cikarang, dapat ditarik kesimpulan sebagai berikut:

1. Para peserta merasa mendapatkan wawasan yang lebih luas tentang cara belajar yang efektif, dan siswa lebih termotivasi kembali untuk berprestasi.

2. Berdasarkan hasil umpan balik dari peserta, didapatkan penilaian bahwa kegiatan ini sangat relevan dengan kebutuhan para siswa SMA, khususnya siswa tingkat XII yang sedang persiapan menjelang ujian akhir nasional dan yang akan mengakhiri masa studi.

\section{DAFTAR PUSTAKA}

Djamarah, Syaiful Bahri. 1994. Prestasi Belajar dan Kompetensi Guru. Surabaya: Usaha Nasional.

Slameto. 1995. Belajar dan Faktor-Faktor yang Mempengaruhinya. Jakarta: Rineka Cipta.

Sugihartono, dkk. 2007. Psikologi Pendidikan. Yogyakarta: UNY Press.

https://ipb.academia.edu/stevanyatok

https://id.wikipedia.org/wiki/Hipnosis 